\title{
Studi Perikanan Tangkap Jaring Insang dengan Shortening Berbeda di Perairan Tompo Pasi Waemputtang Poleang Selatan, Bombana
}

\author{
Study on Gillnet Using Different Shortening in Tompo Pasi Waters of Waemputtang \\ of South Poleang, Bombana
}

\author{
Irma Safriani $^{1)}$, La Sara $^{2 *}$, Naslina Alimina ${ }^{2)}$ \\ ${ }^{1)}$ Program Studi Ilmu Perikanan Program Pascasarjana Universitas Halu Oleo, Kendari, Indonesia \\ ${ }^{2)}$ Fakultas Perikanan dan Ilmu Kelautan Universitas Halu Oleo, Kendari, Indonesia \\ Corresponding author ${ }^{*}$ : lasara_unhalu@yahoo.com
}

\begin{abstract}
The gillnet constitutes a generally fishing gear used by fihermen in Bombana. The mesh sizes and shorthening of gillnets were still based on fishermen experiences from generation to the next generation, even though the right mesh size and shortening is one of the factors determining for the success of fishing. Due to this condition, it needs to develop its optimum shortening. The purpose of study was to determine species composition, diversity index $(\mathrm{H})$, dominance index (C), fishermen income, and better shortening to support ecological and fishermen business sustainability. Samples were collected weekly from October to December 2018 using a gill net of $30 \%$ and $40 \%$ shortenings. Those samples were seperated according to the species and counted each species number. Data obtained were analyzed accoring to species composition. Those data were analyzed to find out diversity index and dominance index using the Shannon-Wienner $(\mathrm{H})$ and the Simpson Index $(\mathrm{C})$, respectively. Bussines income of fishermen was analyzed using Revenue Cost Ratio (R/C ratio) and Payback Period, while to determine a better shortening of size experimented was analyzed using t-test. The result of study showed that diversity idex (H') of both shortening meshes was belong to high category of 1.110 and 1.118 , respectively, while dominance index of both shortening meshes was belong to low category of 0.499 and 0.493 , respectively. The fishermen bussines feasibility showed that fishermen using gillnets of $30 \%$ of shortening was much profitable and feasible to be developed. The result of t-test of catch production of both shortening of $30 \%$ and $40 \%$ showed significant different $(p<0,05)$. It suggests that gillnet fishermen should use gillnet of $30 \%$ shortening.
\end{abstract}

Keywords : Bussines Feasibility, Capture Fisheries, Gillnet, Shortening, Species Diversity.

\begin{abstract}
ABSTRAK
Jaring insang merupakan alat tangkap yang umum digunakan nelayan di Kabupaten Bombana. Penentuan ukuran mata jaring dan shortening masih berdasarkan pengalaman nelayan secara turun temurun, padahal ukuran mata jaring dan shortening yang tepat menjadi salah satu faktor penentu keberhasilan penangkapan. Hal ini perlu adanya pengembangan alat tangkap jaring insang berdasarkan shortening yang optimum. Tujuan penelitian ini adalah untuk menentukan komposisi jenis, Indeks Keanekaragaman $(\mathrm{H})$, Indeks Dominansi (C), pendapatan usaha, dan menentukan shortening yang lebih baik untuk mendukung keberlanjutan ekologi dan keberlanjutan usaha nelayan. Sampel dikumpulkan setiap minggu pada bulan Oktober-Desember 2018 menggunakan jaring insang shortening $30 \%$ dan 40\%. Hasil tangkapan dianalisis komposisi jenisnya dan tingkat keanekaragaman jenis di analisis menggunakan Shannon-Wienner $(\mathrm{H})$, sedang tingkat dominansi spesies dianalisis menggunakan Indeks Simpson (C). Penentuan pendapatan usaha menggunakan analisis Revenue Cost Ratio dan Payback Period. Penentuan shortening yang lebih baik menggunakan statisyik uji-t. Hasil analisis tingkat keanekaragam jenis masing-masing shortening $30 \%$ dan $40 \%$ tergolong kategori tinggi $(1,110$ dan 1,118), sedang Indeks Dominansi masing shortening tergolong rendah $(0,499$ dan 0,493$)$. Hasil analisis kelayakan usaha menggunakan alat tangkap jaring insang shortening 30\% tergolong menguntungkan dan layak untuk dikembangkan. Hasil uji-t menunjukkan bahwa hasil tangkapan jaring insang shortening $30 \%$ dan $40 \%$ menunjukan perbedaan nyata $(\mathrm{p}<0,05)$. Berdasarkan hasil analisis tangkapan ikan menunjukan bahwa direkomendasikan kepada nelayan menggunakan jaring insang shortening $30 \%$.
\end{abstract}

Keyword : Bombana, Jaring Insang, Kelayakan Usaha, Perikanan Tangkap, Shortening 


\section{PENDAHULUAN}

Secara geografis Kabupaten Bombana terletak di bagian tenggara Pulau Sulawesi di selatan garis khatulistiwa, memanjang dari utara ke selatan pada posisi $4^{\circ} 22{ }^{\prime} 59,4^{\prime \prime} \quad-5^{\circ} 28^{\prime} 26,7^{\prime \prime}$ Lintang Selatan (sepanjang sekitar $180 \mathrm{~km}$ ) dan membentang dari barat ke timur pada posisi $121^{\circ} 27^{\prime} 46,7^{\prime \prime}$ $122^{\circ} 09^{\prime} 9,4$ " Bujur Timur (sepanjang sekitar 154 $\mathrm{km}$ ). Wilayah daratan dan lautan daerah ini masingmasing mempunyai luas sekitar $2.969,69 \mathrm{Km}^{2}$ dan sekitar $22.837,31 \mathrm{Km}^{2}$. Daerah ini mempunyai 22 kecamatan dan sebanyak 17 kecamatan adalah kecamatan pesisir.

Sebagian besar masyarakat daerah ini menggantungkan kehidupannya pada sektor kelautan dan perikanan. Sektor perikanan mempunyai nilai strategis dan sangat prospektif untuk dikembangkan, terutama bidang perikanan tangkap. Produksi perikanan tangkap dapat andalkan di daerah ini, seperti ditunjukan data produksi perikanan tangkap pada tahun 2018 sebesar 20.362,4 ton/tahun (DKP Bombana, 2018). Namun demikian, sarana produksi yang dimiliki tergolong tradisional yang ditunjukkan dengan masih dominannya penggunaan kapal/perahu tanpa motor sejumlah 58,78\% dari jumlah total (DKP Bombana, 2015). Salah satu jenis alat tangkap yang banyak digunakan nelayan adalah jaring insang yang mencapai 849 unit yang digunakan oleh 7.655 nelayan (DKP Bombana, 2017).

Salah satu desa di daerah ini yang nelayannya banyak dan telah lama menggunakan alat jaring insang adalah Desa Waemputtang yang terletak di Kecamatan Poleang Selatan (DKP Bombana, 2015). Alat tangkap ini dioperasikan di dasar perairan untuk menangkap berbagai jenis ikan demersal dan pelagis seperti ikan baronang (Siganus sp.), ikan lencam (Lethrinus lentjan), ikan ayam (Acreichthys tomentosus), dan ikan biji nangka karang (Parupeneus indicu). Penggunaan alat tangkap ini secara umum didukung oleh beberapa kelebihan yang dimiliki, yaitu lebih mudah penanganan dan pengoperasiannya, harga alat tangkap relatif murah, mudah diperbaiki, dan relatif tahan lama.

Nelayan di desa tergolong nelayan skala kecil yang pengetahuannya terbatas berdasarkan pengalaman atau kebiasaan. Jaring insang shortening $30 \%$ dan $40 \%$ digunakan nelayan umumnya berdasarkan pengalaman dan kebiasaan yang telah ada. Penelitian tentang penggunaan alat tangkap ini berdasarkan ukuran shorthening dan jumlah hasil tangkapan dan kelayakan usahanya belum pernah dilakukan. Penelitian ini fokus pada hasil tangkapan dan efektivitas alat tangkap jaring insang shorthening $30 \%$ dan $40 \%$, implikasi ekologi penggunaan alat tangkap, dan kelayakan usaha berdasarkan aspek finansial dan kesejahteraan nelayan pengguna alat tangkap. Keberlanjutan sumberdaya (aspek ekologis) dan kesejahteraan nelayan (aspek ekonomi) merupakan tujuan yang ingin dicapai dalam pengelolaan sumberdaya perikanan, khususnya perikanan skala kecil di lokasi penelitian ini. Tujuan penelitian ini adalah menentukan komposisi jenis, indeks keanekaragaman, dan indeks dominansi hasil tangkapan jaring insang shortening 30\% dan 40\%; pendapatan usaha nelayan dan shortening yang lebih baik untuk mendukung keberlanjutan ekologi dan usaha nelayan.

\section{METODE PENELITIAN}

Penelitian ini dilaksanakan di perairan Tompo Pasi Kabupaten Bombana (Gambar 1) Kegiatan survey dan analisis data dilakukan pada bulan Oktober - Desember 2018. 


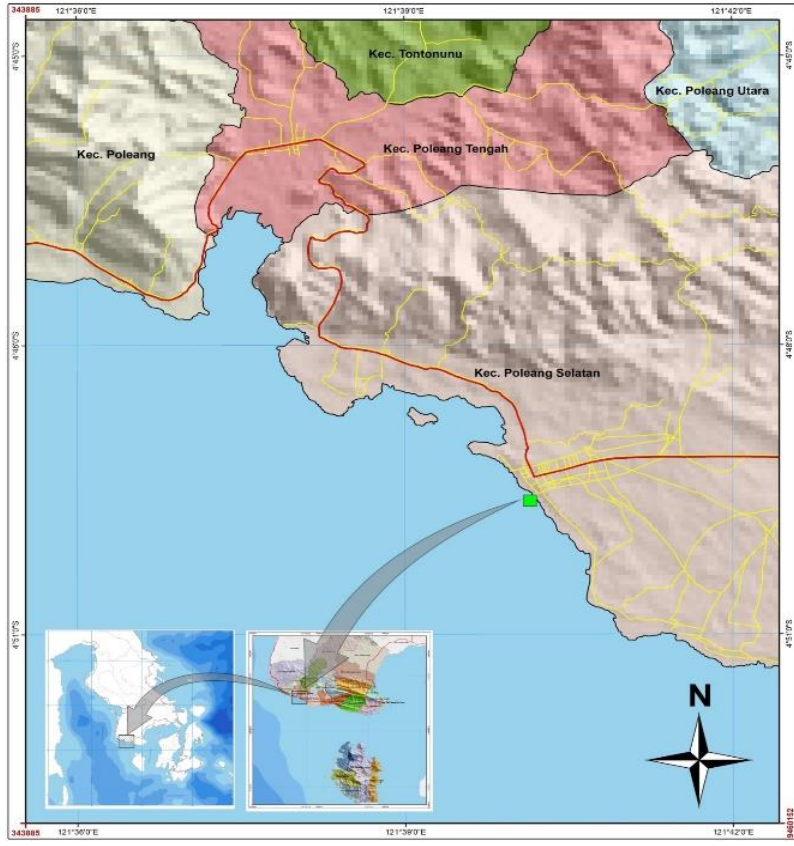

Gambar 1. Peta Lokasi Penelitian

Variabel penelitian ini meliputi jenis dan jumlah individu setiap jenis hasil tangkapan. Jaring insang yang digunakan mempunyai mesh size 2 inci. Perlakuan alat tangkap yang digunakan ada 2 jenis masing-masing mempunyai shortening $30 \%$ dan $40 \%$.

Pengoperasian kedua jenis alat tangkap ini untuk pengujian jumlah dan jenis hasil tangkapan yang dilakukan setiap minggu selama 3 bulan. Pengoperasiannya dilakukan pada sore hari pada kedalaman 3 - 5 m sebagaimana kebiasaan nelayan di daerah ini.

Seluruh hasil tangkapan ikan pada masingmasing jenis jaring insang diambil dan dipisahkan menurut jenis ikan, diidentifikasi berdasarkan Kuiter dan Tanazuka (2001) dan White et al. (2013), ditimbang bobot tubuh setiap individu menggunakan timbangan digital ketelitian $0,1 \mathrm{~g}$, kemudian masingmasing jenis dihitung jumlahnya.

\section{Analisis Data}

\section{Komposisi Jenis}

Komposisi jenis merupakan perbandingan antara jumlah suatu spesies (jenis) dan jumlah total. Hasil tangkapan jaring insang diklasifikasi menurut jumlah tangkapan dari setiap jenis. Komposisi jenis dihitung menggunakan persamaan berikut (Odum, 1996):

$$
\mathrm{Pi}=\frac{\mathrm{ni}}{\mathrm{N}} X 100 \%
$$

keterangan:

$\mathrm{Pi}=$ Komposisi jenis (\%), ke-i, dimana $\mathrm{i}=1,2,3, \ldots \mathrm{n}$

$\mathrm{ni}=$ Jumlah ind tiap spesies ke-i, dimana $\mathrm{i}=1,2,3, \ldots \mathrm{n}$

$\mathrm{N}=$ Jumlah total spesies

\section{Indeks Keanekaragaman}

Keanekaragaman jenis dianalisis dengan indeks keanekaragaman Shannon-Wienner (Krebs, 1989) adalah:

$$
H^{\prime}=-\sum_{i=1}^{s}(P i)\left(\log ^{2} P i\right) ; P i=\frac{n i}{N}
$$

keterangan:

$\mathrm{H}^{\prime}=$ Indeks keanekaragaman jenis Shannon Wiener

$\mathrm{ni}=$ Jumlah individu tiap jenis ke-i

$\mathrm{N}=$ Jumlah total jenis (ind)

Besaran nilai indeks keanekaragaman hasil tangkapan adalah:

$\mathrm{H}^{\prime}>1=$ keanekaragaman tinggi artinya selektivitas alat tangkap rendah

$\mathrm{H}^{\prime}=0=$ keanekaragaman rendah artinya selektivitas alat tangkap tinggi.

\section{Indeks Dominansi}

Dominansi jensi dihitung dengan indeks dominansi Simpson (Odum, 1996):

$$
\mathrm{C}=\sum_{i=1}^{n}\left(\begin{array}{c}
n i \\
\mathrm{~N}
\end{array}\right)^{2}
$$

keterangan:

$\mathrm{C}=$ Indeks dominansi simpson

$\mathrm{ni}=$ Jumlah individu spesies ke-i yang tertangkap dimana $\mathrm{i}=1,2,3, \ldots \mathrm{n}$

$\mathrm{N}=$ Jumlah total spesies yang tertangkap

Kriteria nilai Indeks Dominansi Simpson adalah sebagai berikut:

$\mathrm{C}<0,5=$ Dominansi spesies hasil tangkapan rendah artinya alat tangkap memiliki selektivitas rendah terhadap target penangkapan,

$\mathrm{C}>0,5=$ Dominansi spesies hasil tangkapan tinggi artinya suatu alat tangkap memiliki selektivitas yang tinggi terhadap target penangkapan

\section{Analisis Pendapatan Usaha}

Pendapatan usaha merupakan selisih antara penerimaan yang diterima nelayan dikurangi dengan biaya operasional yang diketahui melalui 
perhitungan pendapatan sebagai berikut (Coelli et al, 1998):

$$
\Pi=\mathrm{TR}-\mathrm{TC}
$$

keterangan:

$\Pi=$ Pendapatan (keuntungan) per tahun

$\mathrm{TR}=$ Total Revenue (total penerimaan) per tahun

$\mathrm{TC}=$ Total Cost (total biaya operasional) per tahun

Kriteria :

- Jika TR>TC, maka usaha jaring insang mendapatkan keuntungan

- Jika TR<TC, maka usaha jaring insang mengalami kerugian

- Jika TR=TC, maka usaha jaring insang berada pada titik impas atau tidak untung ataupun rugi

\section{Analisis Imbangan Penerimaan dan Biaya (Revenue Cost Ratio)}

Analisis $\mathrm{R} / \mathrm{C}$ ratio digunakan untuk mengetahui "keuntungan" suatu usaha selama periode tertentu menggunakan rumus berikut (Umar, 2004):

$$
\mathrm{RC}=\frac{T R}{T C} X 100 \%
$$

Kriteria :

- Jika RC > 1 maka kegiatan usaha tersebut dikatakan untung sehingga layak untuk dilanjutkan,

- Jika RC = 1 maka kegiatan usaha tersebut dikatakan tidak untung dan tidak rugi sehingga berada dalam kondisi impas,

- Jika RC $<1$ maka kegiatan usaha tersebut dikatakan rugi sehingga tidak layak untuk dilanjutkan.

\section{Analisis Waktu Balik Modal (Payback Period)}

Nilai rasio ini dibandingkan dengan maximum payback period yang dapat diterima. Rumus Payback Period sebagai berikut (Umar, 2004):

$$
\mathrm{PP}=\frac{\text { investasi }}{\text { laba bersih }} X 1 \text { Tahun .... }
$$

\section{Analisis Perbandingan Shortening dan Hasil Tangkapan}

Perbedaan jumlah hasil tangkapan jaring insang dengan shortening berbeda dianalisis menggunakan uji-t dengan bantuan software SPSS 24. Uji-t digunakan untuk menentukan apakah dua sampel yang diperoleh dari 2 shortening saling berhubungan satu sama lain, sehingga dua grup tersebut mempunyai nilai rata-rata yang sama atau tidak sama secara signifikan (Gerald, 2018).

Sugiyono (2017) menjelaskan bahwa mengetahui adanya perbedaan jumlah hasil tangkapan menggunakan shortening $30 \%$ dan $40 \%$ menggunakan hipotesis berikut:

$$
\begin{aligned}
& \mathrm{H}_{0}: \mu_{1}=\mu_{2} \\
& \mathrm{H}_{1}: \mu_{1} \neq \mu_{2}
\end{aligned}
$$

keterangan:

$\mu_{1}=$ rata-rata hasil tangkapan shortening $40 \%$

$\mu_{2}=$ rata-rata hasil tangkapan shortening 30\%

Kaidah pengambilan keputusan sebagai berikut: Jika nilai $p<0,05$ maka terima $\mathrm{H}_{0}$ artinya terdapat perbedaan nyata antara hasil tangkapan shortening $30 \%$ dengan shortening $40 \%$, sebaliknya jika $p>$ 0,05 maka terima $\mathrm{H}_{1}$ artinya tidak terdapat perbedaan nyata antara hasil tangkapan shortening $30 \%$ dengan shortening $40 \%$.

Analisis perbedaan hasil tangkapan setiap shortening berdasarkan jumlah individu (spesies) yang diiperoleh. Hasil analisis tersebut menjadi dasar menentukan shortening yang dipilih nelayan yang melakukan penangkapan di perairan Tompo Pasi.

\section{HASIL DAN PEMBAHASAN}

Desa Waemputtang merupakan pemekaran dari Desa Batu Putih Kecamatan Poleang Selatan dengan luas wilayah sekitar $69,40 \mathrm{~km}^{2}$. Jumlah penduduk desa ini 2.244 jiwa dengan jumlah 597 Kepala Keluarga. Masyarakat di desa ini menggantungkan hidupnya pada sektor perikanan dan kelautan, terutama sebagai nelayan yang menggunakan jaring insang.

Perairan Tompo Pasi merupakan daerah penangkapan ikan oleh nelayan jaring insang desa ini pada koordinat $4^{\circ} 49^{\prime} 37^{\prime \prime}$ Lintang Selatan dan $121^{\circ} 40^{\prime} 9$ " Bujur Timur. Sample dalam penelitian ini adalah nelayan yang menggunakan jaring insang dan merupakan pemilik usaha/alat tangkap. Ikan yang ditangkap adalah jenis ikan pelagis dan ikan demersal.

Jaring insang yang digunakan berbentuk empat persegi panjang dengan ukuran mata jaring 2,00 inci. Alat tangkap ini mempunyai pelampung tanda dan pelampung yang melekat pada tubuh jaring. Kedua jenis pelampung tersebut terbuat dari gabus. Pelampung tanda berfungsi sebagai tanda yang menunjukkan tempat pemasangan alat, sedangkan pelampung yang melekat pada tubuh jaring berfungsi sebagai pemberat agar jaring insang berdiri tegak. Pemberat adalah timah diameter $4 \mathrm{~mm}$ yang berfungsi menenggelamkan seluruh badan jaring insang ke dasar perairan. 
40 Safriani et al.

JURNAL SAINS dan INOVASI PERIKANAN / Journal of Fishery Science and Innovation

Vol. 6, No. 1, 36-43, Januari 2022

Kapal penangkap ikan yang digunakan nelayan dalam pengoperasian alat tangkap ini memiliki ukuran panjang $6,5 \mathrm{~m}$ dan lebar $70 \mathrm{~cm}$ dengan umur teknis selama 10 tahun menggunakan mesin 6,5 PK yang dipasang cadik pada sisi perahu yang berfungsi menyeimbangkan perahu.

Pengoperasian alat tangkap jaring insang umumnya dilakukan pagi hari atau sore hari tergantung pada kondisi cuaca. Puncak musim angin barat (Januari - Februari) dan puncak musim angin timur (Juli - Agustus) merupakan musim paceklik usaha penangkapan ikan. Jumlah trip penangkapan ikan ditentukan oleh jarak dan kondisi lingkungan daerah penangkapan. Sebagian besar nelayan melakukan penangkapan ikan satu hari per trip (one day trip) karena jarak daerah penangkapan ikan (fishing ground) relatif dekat. Pada umumnya nelayan jaring insang di daerah ini melakukan penangkapan sebanyak 15 trip/bulan.

\section{Hasil}

\section{Komposisi Hasil Tangkapan}

Komposisi jenis ikan hasil tangkapan jaring insang shortening $30 \%$ dan $40 \%$ hampir menunjukkan tidak ada perbedaan, yaitu masingmasing 7 jenis dan 8 jenis. Jenis-jenis ikan tersebut termasuk ke dalam 6 famili (Tabel 1). Komposisi jenis hasil tangkapan jaring insang masing-masing shortening didominasi famili Labridae, yaitu $28,57 \%$ dan $37,50 \%$.

Tabel 1. Komposisi jenis hasil tangkapan jaring insang

\begin{tabular}{lllcc}
\hline \multirow{2}{*}{ No. } & \multirow{2}{*}{ Famili } & \multicolumn{2}{c}{ Jenis } & \multicolumn{2}{c}{ Shortening } \\
\cline { 3 - 5 } & & & $30 \%$ & $40 \%$ \\
\hline 1. & Siganidea & Siganus sp. & 14.29 & 12.50 \\
2. & Lethrinidae & Lethrinussp & 14.29 & 12.50 \\
3. & Monacanthidae & Acreichthyt sp. & 14.29 & 12.50 \\
4. & Labridae & Choerodon sp. & 28.59 & 37.50 \\
& & Cheilinus sp. & & \\
& & Chelioinermis \\
5. & Pomacentridae & Neoglyphidodon sp. & 14.29 & 12.50 \\
6. & Mullidae & Parupeneus sp. & 14.29 & 12.50 \\
\hline \multicolumn{3}{c}{ Jumlah } & 100 & 100 \\
\hline
\end{tabular}

\section{Indeks Keanekaragaman}

Nilai indeks keanekaragaman jenis hasil tangkapan jaring insang shortening 30\% dan $40 \%$ masing-masing 1,074 dan 1,118. Kedua nilai tersebut tergolong kategori keanekaragaman tinggi (Tabel 2).
Tabel 2. Indeks keanekaragaman jenis hasil tangkapan jaring insang

\begin{tabular}{ccc}
\hline $\begin{array}{c}\text { Jaring Insang } \\
\text { Shortening }\end{array}$ & $\begin{array}{c}\text { Indeks } \\
\text { Keanekaragaman }\end{array}$ & Keterangan \\
\hline $30 \%$ & 1,074 & Tinggi \\
$40 \%$ & 1,118 & Tinggi \\
\hline
\end{tabular}

Indeks Dominansi (C)

Indeks dominansi jenis hasil tangkapan jaring insang shortening 30\% dan 40\% masing 0,507 dan 0,493 . Nilai indeks dominasi tersebut tergolong kategori Indeks Dominansi rendah (Tabel 3)

Tabel 3. Indeks dominansi hasil tangkapan jaring insang

\begin{tabular}{ccc}
\hline $\begin{array}{c}\text { Jaring Insang } \\
\text { Shortening }\end{array}$ & Indeks Dominansi & Keterangan \\
\hline $30 \%$ & 0,507 & rendah \\
$40 \%$ & 0,493 & rendah \\
\hline
\end{tabular}

\section{Analisis Pendapatan Usaha Jaring Insang}

Total biaya yang keluarkan oleh pemilik usaha penangkapan menggunakan jaring insang shortening $30 \%$ dan $40 \%$ masing-masing sebesar Rp 7.434.000 dan Rp 8.250.000. Total penerimaan nelayan jaring insang shortening $30 \%$ dan $40 \%$ masing-masing sebesar Rp 14.400.000 dan Rp 10.800.000. Dengan demikian keuntungan yang diterima untuk masingmasing jaring insang shortening adalah $\mathrm{Rp}$ 6.966.000/tahun dan Rp 2.550.000/tahun (Tabel 4).

Tabel 4. Hasil Analisis Pendapatan Usaha Jaring Insang

\begin{tabular}{clrc}
\hline No. & \multicolumn{1}{c}{ Komponen } & $\begin{array}{c}\text { Shotening } \\
30 \%\end{array}$ & \multicolumn{1}{c}{$\begin{array}{c}\text { Shotening } \\
40 \%\end{array}$} \\
\hline 1. & Total penerimaan (Rp) & 14.100 .000 & 10.800 .000 \\
2. & Biaya yang & 7.434 .000 & 8.250 .000 \\
& dikeluarkan $(\mathrm{Rp})$ & & \\
3. & Keutungan $(\mathrm{Rp})$ & 6.966 .000 & 2.550 .000 \\
\hline
\end{tabular}

\section{Analisis Imbang Penerimaan dan Biaya (R/C- Rasio)}

Analisis R/C-rasio adalah perbandingan antar total penerimaan dan total biaya. Hasil analisis R/Cratio jaring inang shortening $30 \%$ dan $40 \%$ masingmasing sebesar 1,9 dan 1,3 (Tabel 5).

Tabel 5. Hasil analisis R/C-ratio jaring insang

\begin{tabular}{lrr}
\hline No. Komponen & $\begin{array}{r}\text { Shortening } \\
30 \%\end{array}$ & \multicolumn{1}{c}{$\begin{array}{c}\text { Shotening } \\
40 \%\end{array}$} \\
\hline 1. Total Penerimaan (Rp) & 14.100 .000 & 10.800 .000 \\
2. Biaya yang dikeluarkan & 7.434 .000 & 8.250 .000 \\
(Rp) & & \\
3. R/C-rasio & 1,94 & 1,31 \\
\hline
\end{tabular}




\section{Analisis Payback Period (PP)}

Analisis PP bertujuan untuk mengetahui berapa lama waktu yang diperlukan untuk menutup biaya investasi. Payback period usaha jaring insang shortening 30\% dan 40\% masing-masing 0,9 tahun dan 3,3 tahun (Tabel 6).

Tabel 6. Analisis payback period (PP) jaring insang

\begin{tabular}{crc}
\hline No. & Komponen & Payback Period (PP) \\
\hline 1. & Shortening 30\% & 0,9 Tahun \\
2. & Shortening $40 \%$ & 3,3 Tahun \\
\hline
\end{tabular}

\section{Analisis Perbandingan Hasil Tangkapan Jaring Insang Shortening 30\% dan $40 \%$}

Hasil uji-t terhadap jumlah ikan yang tertangkap pada jaring insang shortening $30 \%$ dan $40 \%$ menunjukkan perbedaan nyata $(\mathrm{p}<0,05) \quad\left(\mathrm{H}_{0}\right.$ diterima).

\section{Pembahasan}

Hasil tangkapan ikan selama penelitian menunjukkan bahwa sumberdaya ikan di perairan Tompo Pasi cukup beragam. Hasil tangkapan jaring insang shortening $30 \%$ dan $40 \%$ masing-masing sebanyak 265 ekor dan 149 ekor. Hal ini menunjukan bahwa jaring insang shortening pada alat tangkap lebih berpengaruh terhadap cara ikan tertangkap.

Semakin tinggi shortening jaring inang maka bukaan mata jaring semakin sempit. Data ini berbeda dengan hasil penelitian Chaidir et al., (2019) tentang komposisi jenis hasil tangkapan bagan rambo di perairan Teluk Lasolo Kabupaten Konawe Utara yaitu berjumlah 37.881 individu yang terdiri atas 50 spesies, masing-masing 46 spesies ikan dari 24 famili dan 2 kelompok non ikan masing-masing 3 spesies mollusca dan 1 spesies crustacea. Dua penelitian ini menunjukan bahwa komposisi jenis hasil tangkapan salah satu yang mempengaruhinya adalah jenis alat tangkap yang digunakan. Nofri et al. (2015) menyatakan bahwa perlakuan shortening pada jaring insang tidak berpengaruh terhadap hasil tangkapan. Pada shortening $40 \%$ lebih dominan ikan tertangkap secara etangled (terpuntal) karena ikan yang tertangkap memiliki ukuran relatif besar sehingga ikan tidak terjerat pada mata jaring melainkan terpuntal pada badan jaring, sedang shortening 30\% lebih dominan ikan tertangkap secara wedged (terbelit), karena ukuran ikan yang tertangkap memiliki ukuran relatif lebih kecil sehingga ikan terjerat pada mata jaring. Nomura (1985) menyatakan bentuk bukaan mata jaring yang tidak sesuai dengan bentuk badan ikan target dapat menyebabkan ikan hanya menabrak mata jaring dan selanjutnya meloloskan diri.

Indeks ekologi yang ditunjukan oleh hasil tangkapan jaring insang dengan shortening 30\% dan $40 \%$ ditunjukan oleh nilai indeks keanekaragaman (H') (Tabel 2). Indeks keanekaragaman (H') jenis ikan yang tertangkap dengan kedua tipe alat tangkap yang digunakan tergolong kategori tinggi $\left(\mathrm{H}^{\prime}>1\right)$. Tinggi dan rendahnya nilai indeks keanekaragaman jenis disebabkan oleh berbagai faktor, antara lain jumlah jenis atau individu yang diperoleh, adanya beberapa jenis organisme yang ditemukan dalam jumlah yang melimpah, homogenitas substrat dan kondisi ekosistem penting di daerah pesisir (Supono dan Arbi, 2010). Nilai indeks keanekaragaman yang diperoleh ini juga mengindikasikan bahwa selektivitas alat tangkap yang digunakan ini rendah. Selektivitas adalah sifat alat tangkap dalam memperoleh hasil tangkapan dengan ukuran tertentu dan spesies dari sebaran populasi (Tambunan et al., 2010). Alat tangkap yang kurang selektif ditunjukkan dengan banyaknya jenis ikan yang tidak dapat meloloskan diri dari jaring. Alat tangkap yang tidak selektif dari segi ukuran dan jenis kelamin organisme seperti kepiting bakau bisa mengancam keberlanjutan populasinya (Rosmiati et al., 2019).

Nilai indeks dominasi yang diperoleh tergolong kategori rendah (Tabel 3). Hal ini membuktikan bahwa jenis ikan tidak ada yang mendominasi secara spesifik atau temporal. Nilai indeks ini menunjukan kondisi perairan daerah penangkapan ikan nelayan dalam keadaan stabil. Nilai indeks dominansi juga mencerminkan efektivitas alat penangkapan ikan yang digunakan (Wiyono, 2006). Purnama et al., (2011) menjelaskan bahwa adanya dominansi menunjukkan tempat tersebut memiliki kekayaan jenis yang rendah. Nilai indeks dominansi mencermikan efektivitas suatu alat penangkapan ikan (Hakim, 2017).

Hasil tangkapan ikan yang diperoleh nelayan menggunakan jaring insang dengan 2 tipe shortening menggambarkan besarnya penerimaan yang diperoleh. Penerimaan yang diterima nelayan cukup baik karena dapat menutupi biaya operasional yang dikeluarkan. Data penerimaan nelayan ini dapat menjamin keberlanjutan usaha penangkapan ikan menggunakan jaring insang.

Nilai R/C-ratio usaha perikanan jaring insang shortening $30 \%$ dan $40 \%$ layak untuk dikembangkan 
karena nilai $\mathrm{R} / \mathrm{C}>1$. Hal ini menunjukan bahwa usaha perikanan tangkap jaring insang di perairan ini dikatakan memberi untung dan layak untuk dikembangkan. Hasil analisis R/C-rasio ini menunjukan kelayakan suatu usaha. Bila nilai R/Cratio $=1$ berarti usaha tersebut belum mendapatkan keuntungan sehingga perlu pembenahan. Semakin kecil nilai R/C-ratio maka semakin besar kemungkinan kegiatan usaha mengalami kerugian (Hartini, 2018).

Nilai PP penggunaan jaring shortening $30 \%$ dan $40 \%$ masing-masing membutuhkan waktu pengembalian modal investasi 9 bulan dan 3 tahun 3 bulan menggunakan seluruh pendapatan yang diperoleh. Tingkat pengembalian modal pada usaha dikategorikan cepat jika nilai PP kurang dari 3 tahun, sedang PP > 3 tahun tetapi kurang dari 5 tahun berarti tergolong kategori tingkat pengembalian sedang. Golongan kategori lainnya adalah apabila nilai $\mathrm{PP}<5$ tahun maka termasuk kategori tingkat pengembalian lambat (Riyanto, 1991). Walaupun demikian, hasil uji-t menunjukkan bahwa kedua tipe jaring insang yang digunakan menunjukan perbedaan tidak nyata terhadap jumlah total hasil tangkapan ikan.

\section{KESIMPULAN}

Berdasarkan analisis yang dikemukakan di atas maka hasil penelitian ini dapat disimpulkan bahwa : Jaring insang yang digunakan nelayan dengan 2 tipe shortening $30 \%$ dan $40 \%$ mempunyai komposisi jenis hasil tangkapan didominasi famili Labridae yang menunjukan bahwa lokasi penangkapan nelayan didominasi oleh jenis ikan famili Labridae. Indeks ekologi yang dianalisis seperti Indeks Keanekaragaman hasil tangkapan jaring yang digunakan 2 tipe shortening 30\% dan $40 \%$ tergolong kategori tinggi atau kedua tipe alat tangkap yang digunakan mempunyai selektivitas rendah. Indeks ekologi lainnya yaitu Indeks Dominansi hasil tangkapan jaring insang yang digunakan 2 tipe shortening 30\% dan $40 \%$ tergolong kategori rendah yang menunjukan bahwa tidak ada jenis ikan yang mendominasi perairan ini. Analisis pendapatan usaha dan R/C-ratio penangkapan ikan menggunakan jaring insang layak dikembangkan. Walaupun demikian, usaha penangkapan menggunakan jaring insang shortening $30 \%$ lebih layak dibandingkan dengan shortening $40 \%$ dengan jangka waktu pengembalian biaya investasi berturut-turut 0,9 tahun dan 3,3 tahun. Hasil uji-t menunjukan bahwa total jumlah ikan yang tertangkap mengunakan jaring insang shortening $30 \%$ dan $40 \%$ menunjukkan perbedaan tidak nyata.

Saran, jaring insang yang dioperasikan di perairan Tompo Pasi Desa Waemputtang sebaiknya menggunakan shortening $30 \%$ karena hasil tangkapan lebih efisien. Alat tangkap ini tetap memperhatikan kelestarian sumberdaya dan meningkatkan produktifitas hasil tangkapan yang dapat meningkatkan taraf hidup nelayan.

\section{DAFTAR PUSTAKA}

Coelli T, Rao DSP, Bettese GE. 1998. An Introduction to productivity analisis. Springer: United States of America.

Chaidir Z, La Sara, Alimina N. 2019. Hasil tangkapan utama dan tangkapan sampingan bagan rambo di perairan Teluk Lasolo Kabupaten Konawe Utara. Jurnal Sains dan Inovasi Perikanan. 3 (2): 39-44.

Dinas Perikanan dan Kelautan Bombana. 2015. Data Statistik. Perikanan Kabupaten Bombana.

Dinas Perikanan dan Kelautan Bombana. 2017. Data Statistik. Perikanan Kabupate Bombana.

Dinas Perikanan dan Kelautan Bombana. 2018. Data Statistik. Perikanan Kabupaten Bombana.

Gerald B. 2018. A brief review of independent, dependent and one sample t-test. International Journal of Applied Mathematics and Theoretical $\begin{array}{llll}\text { Physics. } & 4 & \text { (2): } & \text { 50-54. }\end{array}$ http://www.sciencepublishinggroup.com/j/ijamtp

Hakim L, Nurhasnah. 2017. Analisis produktivitas, dominansi dan diversitas hasil tangkapan gillnet. Seminar Nasional Riset Inovatif. Jurusan Pemanfaatan Sumberdaya Perikanan. IPB

Hartini S, Sumaryam S. 2018. Efisiensi penggunaan alat tangkap bubu (trap) yang berbeda terhadap pendapatan nelayan rajungan (Portunus pelagicus) di Desa Kemantren Kecamatan Paciran Kabupaten Lamongan Jawa Timur. Jurnal Ekonomi dan Bisnis. 3 (2): 791-810.

Krebs CJ. 1989. Ecological Methodology. Harper Collins Publishers, New York. 654p.

Nofri Y, Sofyan I, Brown A. 2015. The effect of shortening the difference catches gill net fishing gear. Jurnal of Fisheries and Marine Science. 3(1): $1-12$.

Odum EP. 1996. Dasar-Dasar Ekologi. Edisi ketiga (terjemahan). Gajah Mada University Press. Yogyakarta. Hlm 20-32 
Purnama PR, Nastiti NW, Agustin ME, Affandi M. 2011. Diversitas gastropoda di Sungai Sukamade, Taman Nasional Meru Betiri, Jawa Timur. Departemen Biologi Fakultas Sains dan Teknologi. Universitas Airlangga. Surabaya.

Rahantan A, Gondo P. 2012. Ukuran mata jaring dan shortening yang sesuai untuk jaring insang yang dioperasikan di Perairan Tual. Jurnal Marine Fisheries. 3 (2): 141-147.

Riyanto B. 1991. Dasar-dasar pembelanjaan perusahaan. Penerbit BPFE. Yogyakarta. 399 hal.

Rosmiati, La Sara, Yusnaini. 2019. Keragaan spesies dan seks rasio kepiting bakau (Scylla sp) berdasarkan kerapatan mangrove di muara Sungai Wawoone, Konawe. Jurnal Sains dan Inovasi Perikanan. 3 (2): 60-67.

Sugiyono. 2017. Metode penelitian pendekatan kuantitatif, kualitatif, dan R\&D. Alfabeta. Bandung. 334 hal.

Suparjo S, Djumanto. 2014. Komposisi ikan hasil tangkapan jaring insang pada berbagai shortening di Waduk Sermo. Jurnal Perikanan (J. Fish. Sci). XVI (1): $35-42$

Supono, Arbi UY. 2010. Struktur komunitas echinodermata di padang lamun Perairan Kema, Sulawesi Tenggara. Jurnal Oseanology dan Limnologi Indonesia. 3: 329-341.

Tambunan SBS, Fauziyah, Agustriani F. 2010. Selektivitas drift gillnet pada ikan kembung lelaki (Rastrelliger kanagurta) di Perairan Belawan Pantai Timur Sumatera Utara Provinsi Sumatera Utara. Maspari Journal. 1(1): 63 - 68.

Umar H. 2003. Studi kelayakan bisnis: teknik menganalisis kelayakan rencana bisnis secara komprehensif. Gramedia Pustaka Utama. Jakarta. 488 hal.

White WT, Last PR, Dharmadi, Faizah R, Chodorojah U, Prisantoso BI, Pogonoski JJ, Puckridge M, Blader SJM. 2013. Jenis-jenis ikan di Perairan Indonesia. Canberra ACT. Australia. $155 \mathrm{hlm}$.

Wiyono ES, Yanada S, Tanaka E, Arimoto T, Kitakado T. 2006. Dynamic of fhising gear allocation by fisheris in small-scale coastal fisheries of Palabuhan Ratu Bay, Indonesia. Fisheries Management and Ecology. 13 (3): 185 195. 